\title{
居住空間構成法と分裂病者 \\ ARCHITECTURAL SPACE MONTAGE TECHNIQUE AND SCHIZOPHRENIC PATIENT
}

\author{
岡崎甚幸*, 伊藤達彦** \\ Shigeyuki OKAZAKI and Tatsuhiko ITO
}

\begin{abstract}
Architectural Space Montage Method was thought up by authors. Subject's mental image is expected to be represented by miniatures 1 to 50 scale such as units of walls, furnitures, people and trees on a white plate $60 \mathrm{~cm} \times 90 \mathrm{~cm}$. Schizophrenic patients try to make a model of the ideal ward in mental hospital. This method would not deteriorate psychopathology because of forming only dairy living space unlike sandplay therapy. Framing, disturbed association of ideas and preference of protected space were represented on their own works. This method might be a useful therapy in near future because of interests by patients, endurance and impetus to patients.
\end{abstract}

Keywords : mental image, schizophrenic patient, mental hospital, sandplay theropy, framing, preference of protected space 心像，精神分裂病者，精神病院，箱庭療法，枠付け，庇護的空間

序

我々は分裂病患者が大半である精神病院の設計に当面 し，患者達の世界を受け入れる生活空間としての理想の

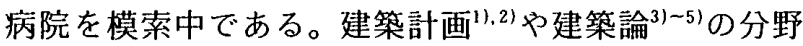
で先駆的研究が行われているが，ここでは閉鎖性とか枠 付け問題等々の患者の世界に特異な現象を具体的なモデ ルの上に投影し，それによって患者の必要とする建築空 間の解明に向けての基礎的な知見を得ようとする。

そこで風景構成法や入院中の病院の認知図による実験 を試みたが，我々も患者も余り楽しくなく解釈も困難を 極めた。また箱庭療法の建築学的研究6) -99 も精力的に進 められているが，分裂病には発症促進的なことがあり危 険である ${ }^{10)}$ 。の時ふと思いついたのが, 模型実験であっ た。病院のさまざまな道具, 例えばベッドや椅子やテー ブルを箱庭療法の道具のように作る。壁をモデュールに 合わせて, さらに出入口や空のあるもの, 色別等各種揃 えそそれらの下に磁石を張り付けてホワイトボードの上 に自立させ, 道具と一緒に部屋や廊下を構成して行く。 さらに患者や医師，看護婦等の人形を作る。人形の中か ら自分人形を選ばせる。病院の内部のみならず，外部の 木や芝生，プール等も作っておいた。実験を重好る度に， 被験者に欲しい道具を尋ねて, 少しずつ増やしていった。 風景構成法にちなんで居住空間構成法と呼ぶことにし
た。

ところが患者たちは，この実験を始めると夢中になっ た。はじめは座っているが，道具を取るため，立ったり 座ったりしているうちに，いつの間にやら立ったままに なり，少なくとも 1 時間以上は続けることになる。楽し いと口々に言う。普段, 作業療法では根気のない, 病状 の安定しない，長期入院患者でもそうであった。予想外 のことであった。そしてまた作りたがった。われわれも 1 時間余, 記録を取りながらその作成過程を観察し, 終 わるとどっと疲れが出た。ただ何十年も入院している無 気力, 好裖性の慢性分裂病患者にはあまり好まれなかっ た。しかし以下に示すような面白い結果が出てきた。何 よりも画用紙に描いたものより迫力があった。また患者 も自分の作った作品に大変満足した。我々も実験後, 作 品の写真を撮影し，それを壊すのをいつももったいない と思った。写真には表現できない迫力を作品の前に座る と感じた。健常者との比較もし，十分な違いがあった。 また制作過程の変化も興味深かった。

各実験での詳細な記録を読み，作品のカラー写真を見 るのが一番であるが，それは膨大な量であり，この論文 報告集で，それらを報告するのは不可能である。従って ここではその要点の紹介にとよ゙めた。また患者の病歴を 全てここに記述することはプライバシーの問題にも関わ
* 福井大学工学部環境設計工学科 教授 $\cdot$ 工博

**福井県立精神病院 医長・医博
Prof., Dept. of Architecture and Civil Engineering, Faculty of Engineering, Fukui Univ., Dr. Eng. Fukui Prefectural Mental Hospital, Dr. Med. 
り不可能である。さらに大勢の患者にこの方法を試して もらうことも現時点では不可能である。これによって分 裂病患者の普遍的世界についてまとめられるものでもな い。しかし我々の考えた新しい方法の有効性を問いつつ も,この方法が患者の世界をある程度具体化しているこ とも事実であった。

河合はユングにもとづいて箱庭を意識と無意識, 内界 と外界の交錯するところに生じた心的な内容を具象的, 直接的, 集約的に表現した視覚的な心像亡見る ${ }^{11}$ 。例え ば自然 (山, 海), 動物 (犬, 猫), 図形 (円, 直線) の 三つの概念に対して母 (海, 猫, 円), 父 (山, 犬, 直線) の二つの心像があると河合はユングの心像 ${ }^{12)}$ を説く。山 中 $^{131}$ は心像は知覚対象のない場合の視覚像と言うより, 外的客体の知覚とは間接的な関連しか持たず, 内的要求 への適応に方向付けられた, エングの無意識的空想の活 動にもとづくものに近いとする。この居住空間構成法も 心像亡考える。ただ箱庭に比べて対象が建築的空間に， ここでは病院に限定され, そのための道具も限定された もとでの心像である。

心像はまた衛藤 ${ }^{24}$ の言う「世界図式」であり, 内的基 準としての以下の性質を持つ。すなわち「風景の組織化 と統合のためには, 主体内部に先行的に何らかの内的基 準が要請される。これは地図のような事物の空間配列指 示ではなく, それに先立ちあらゆる事物の空間配置の可 能性を保証し，そのために奥行きと広がりを持った基本 的空間性を目に見えない形で支えている基準である。」 このようにして病者の建築空間もまたその心像に支えら れて現象する。

当研究の成果のすべてが病院空間の構成に直接役立つ とは限らない。なぜなら例えば実験で奥行き知覚の障害 が現れる破瓜型分裂病患者が，日常生活の場で距離を間 違うと言う証拠もないからである。障害されているのは イメージとしての距離, 心的な距離だからである。描画 という空間構成はそうした心的距離の機能に依存してい ると言う ${ }^{14)}$ 。

各被験者の作品群を細々と分析すればするほど, 個々 の作品は元の姿から遠ざかってしまう。ある時は描画自 体が報告であっても良い占)。ただ河合は個々の作品は全 て異なり，お決まりの解釈なよ゙ないと言いながらも受容 的に作品を見るには解釈が必要であり，正しい解勫には 受容的態度が必要であるとし, 統合性, 空間配置, 主題 について論じている ${ }^{11 !}$ 。また内在的諭理の読取りには描 画プロセスも有効である(5)。ここでは各作品について紙 面の許す限り説明し，同時に壁の形や色など量的に分析 可能なものについてはそれを試みた。

\section{1.この方法の特性}

1) 発症促進的効果

居住空間構成法は箱庭療法に較べ患者の悪い部分を引 き出す恐れが少ない。それは対象の特定建筑空間への限 定による。一方箱庭療法の対象には限定がなく道具には 蛇や怪獣等の非日常的で感情的に強い破壊的性格の道具 が多いからである。

\section{2) 抽象物之具体物}

箱庭療法の道具はすべて具体的なものであるが，居住 空間構成法に備えられた道具は，家具や人形などの具体 的形をしたものと同時に，様々な大きさ，色，空をもつ 壁がある。壁は組み合わせて始めて空間を構成する。そ れ以前は極めて抽象的，幾何学的道具である。これによ り作成者の具体的世界と抽象的世界の間の移行を明らか にできる。

3) 描画能力と解釈

多種類の壁や家具類を置くだけで空間を構成するた め, 描画能力が空間構成を左右し難い。また描出された 空間の解釈もしやすい。

4) 患者の興味

患者や児童が描画より居住空間構成法に興味を示し， 終了後是非またやりたいと言う。作業療法でも根気のな い, 病状の安定しない分裂病患者でも，1 時間連続して居 住空間構成法に夢中になれる。

5）日常性

箱庭療法や風景構成法に較べて当方法の作品は 3 次元 で, しかも生活空間そのものである。そのため作品の中 に身近に住込め，直接的な刺激を受けやすい。

6) 自己表現

何体かの人形の中から自分を選んで置くため，自分と 他人之の関係, 自分の好きな場所, 肉体的, 精神的自己 像が表現される。

\section{2. 实験方法}

\section{1）実験場所}

幅 $3.6 \mathrm{~m}$, 奥行き $5.4 \mathrm{~m}$ の精神病院の一室である。被 験者は空に向かって机の前に座る。机の上には大型ホワ イトボードが水平に置いてある。その両サイドに小型ホ ワイトボードが左右に 2 枚ずつ置いてある。小型ホワイ トボードの上に各種の壁が形別, 色別に整理して立てて ある。その他の道具は奥行き $14 \mathrm{~cm}$, 高さ $60 \mathrm{~cm}$, 幅 86 $\mathrm{cm}$ の二つの黒い棚に整理して並べられた。並んだ二つ の棚は被験者の横に立ててある。

2) 道 具

大型ホワイトボード 1 枚 $(60 \mathrm{~cm} \times 90 \mathrm{~cm})$, 小型ホワ イトボード 4 枚 $(30 \mathrm{~cm} \times 45 \mathrm{~cm})$, 道具の縮尺は全て 50 分の 1 。 


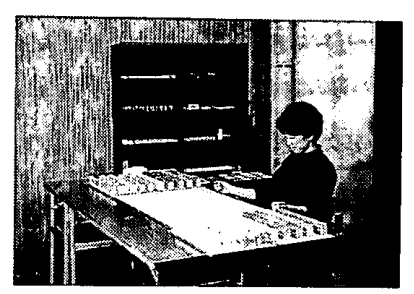

写真一1 制作風景

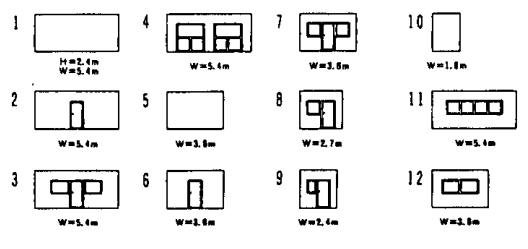

図一1壁の形状リスト

2-1）環 境

2-1-1） 壁

厚さ約 $5 \mathrm{~mm}$ のスチレンボードの各面に各種の色紙を 貼り，空，屝等を切り抜いて，そこに透明プラスチック をはめ込み，屝や空枠を細いビニールテープで表示した もの。さらに壁の下に薄い磁石板を張り付けて自立する ようにしてある。12 種類の形の壁を作り，10 種類の色 紙を貼ったものと木製のものがある。高さは一応天井ま でと仮定し $2.4 \mathrm{~m}$ とした。壁の長さは $5.4 \mathrm{~m}, 3.6 \mathrm{~m}$, $2.7 \mathrm{~m}, 2.4 \mathrm{~m}, 1.8 \mathrm{~m}$ の 5 種類である。壁のユニットの 総数は 459 枚である。10 種類の色紙をマンセル記号で 近似すると以下の通りである。「記号（呼名/マンセル色 系統/マンセル記号/日本名)」の形式で表示する。P（ピ ンク/pale beige/2. 5 YR 8.5/ペール・ベージュ), M(ミ ント/greenish white/10.0G8.5/ミスト・ホワイト), N (ネズミ/white/N 8.5/スノー・ホワイト)，I（アイ ボリー/yellowish white/5.0Y8.5/アイボリー・ホワイ ト), C(クリーム/pale beige/10.0 YR 8.5/ペール・ベー ジュ), W (白/white/N 9.5/スノー・ホワイト), R (レ ンガ/reddish brown/7.5 R 4.5/ブリック・レッド), B (ブルー/sky (light blue)/3.75 PB 7.5/スカイ・ブ ルー), G（緑/soft yellow green/5.0 GY 7.0/ティー・ グリーン), Y (からし/dull reddish yellow/2.5Y7.0/ 八ニー・スイート)

2-1-2) 床

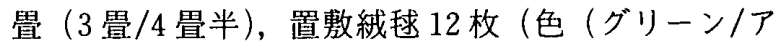
イボリー/ライトスカイ/レンガ/イエロ/グレー), 形 (角 /円))

2-1-3）洗面 ·便所 · 風呂

手洗い 4 個, 洗濯機 5 個, 小便器 3 個, 個室便所 8 個, 共同便所 6 個, 風吕 2 個

2-1-4） 家具

ベッド 45 個, ソファー 15 個, L 型ソファー 2 個, ロングソファー 1 個, 椅子（背付（茶 21 個/赤 14 個/青
16 個/黄 30 個)/高い背付き 7 個/円椅子 5 個)，机（事 務机 10 個/小テーブル 10 個/中テーブル 10 個/大テーブ ル 1 個), ロッカー 10 個, テレビ 5 個

2-1-5) 遊具

麻雀台 1 個, カラオケ 1 台, 卓球台 1 台 2-1-6） その他の道具

電話 (赤 3 台/緑 3 台), 自動販売機 2 台, ナースカウ ンター 1 台, 売店ショウケース 1 台, 階段 1 , バルコ ニ- 12 , 玄関 1 ，プール 1

2-2）人間

医師 2 人, 看護士 1 人, 看護婦 4 人, 男患者 11 人, 女患者 12 人

2-3） 動物

犬 2 匹，猫 2 匹

2-4）植物

樹木 7, 観葉植物 10, 芝生 4

3）被験者への説明

全被験者に同意を得て実験に参加してもらう。実験の 前, 著者達によって以下の説明が行われる。まず各道具 の説明をする。特定の道具だけを詳しく説明しない。そ の道具から使い始めることがある。「道具を使って理想 の病棟を作って下さい。」「人形の中から自分の人形を決 めて好きな時，好きなところに置いて下さい」「時間は いくらかかっても構いません」「完成したらそう言って 下さい」と言う。制作中に質問はしない。ただし「楽し そうですね。」とか「病院らしくなりましたね」と言う 励ましの言葉は与えた。これによって患者は大変勇気づ けられた。そのうち結果を心配していた患者達は心から この遊びを楽しむようになる。大半の患者が椅子から 立ったままで制作に夢中になる。ときどき座って作成す るように促すが，すぐまた立ったままになる。またたく 間に 1 時間ほよ゙が経過する。実験後こちらもどっと疲れ がでる。完成したら，作品について質問する。

実験に参加した分裂病者による壁，窓，扉などの区別 は完全に行われた。

\section{3. 被験者}

入院中の分裂病患者と健常者は表一1の通り。

表一1 被験者

\begin{tabular}{|c|c|c|c|c|c|c|c|}
\hline 氏名 & 年柃中 & 病名 & 霍疗 & 期間 & 入院期間 & 病棟 & 学歴 \\
\hline $\mathrm{K} \mathrm{i}$ & 25男 & 柍神分致病 & （破瓜·妄想型） & 6年 & 2年 & 開放 & 大中退 \\
\hline Yo & $23 女$ & 精神分裂病 & （妄想·粠镸型） & 2 年 & 9力月 & 閉鎖 & 大中退 \\
\hline$M o$ & 43 女 & 慢性分裂病 & （妄想·破血型） & 18 年 & 7 年 9力月 & 開銷 & 高卒 \\
\hline ok & 45男 & 䭪性分裂病 & （破瓜·妄想型） & 28 年 & 19年10力月 & 月閒放 & 高卒 \\
\hline $\mathrm{Mi}$ & 41女 & 惯性分程病 & (破血型) & 22 年 & 9 年 3力月 & 開放 & 高卒 \\
\hline $1 \mathrm{~s}$ & 41男 & 情性分裂病 & (破筫型) & 21年 & 15 年 5力月 & 開放 & 大卒 \\
\hline Se & $22 女$ & & 教育学部学 & & & & \\
\hline$Y$ a & 23男 & & 工学部学生 & & & & \\
\hline Fu & 20 女 & & 工学部学生 & & & & \\
\hline
\end{tabular}




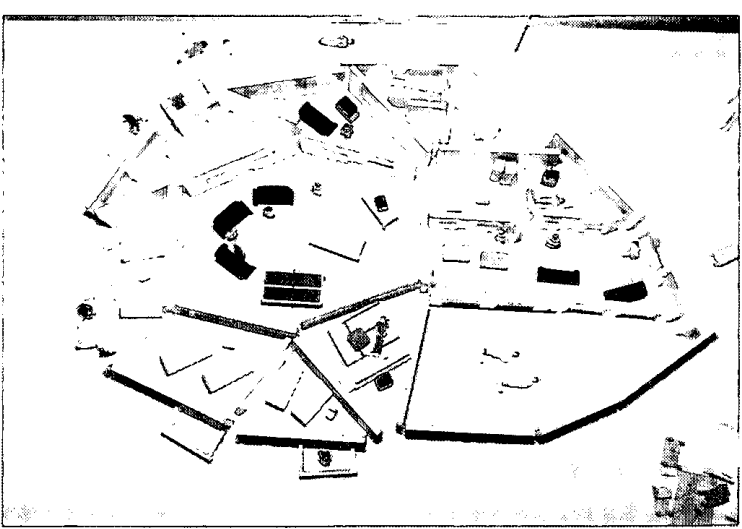

写真一2 被験者 ki の作品

\section{4. 居住空間棈成法の実験結果}

実験 1 被験者 $\mathrm{Ki}$ 両親は本人発病後病死 同胞 2 人第二子 高卒後学業極めて優秀 予備校在籍中発病 昭和 61 年 6 月より大学病院での計 19 ケ月 2 度の入院治 療後平成 3 年 4 月当院入院 日中は家具工場勤務 不全 寛解にあるが自発性欠如が前景

実験 1 回目 所用時間 30 分（午後 1 時 17 分 1 時 47 分）実験の説明をすると「ああ，面白そうですね」と興 味を示す禺ナースセンターのカウンターを置き，その周 りを多角形に囲いデイルームにする。その中に青い服の 人形の自分を選んでおく。ピンクの壁が多い【デイルー ムの外にもう一重の壁を巡らし，その間が病室だと言う。 まだ病室相互の壁はできていない。畳をデイルームにお く。その上にテレビを置く。「デイルームから病室がま る見えのもどうか」と言って, 空付きの壁を窓なしの壁 に変更。しかし「通り抜けるようにしておく」と言って 空付きから出入口付きの壁に変更。デイルームに椅子, 卓球台をおく。トイレを造る。共同便所である。個室型 の便所は見向きもしない。病室にベッドを二つずつ置く。 小さな椅子を一つずつ各病室に置く。「個室よりも二人 部屋がよい」と言う。「皆の共同の部屋を造るかな」と デイルームの奥の方にもう一つの共同室ができる。看護 婦をナースセンターに置く。「もっとベランダありませ んか」。「゙レーはいや」とピンクのベランダを多く使う。 ビの部屋にもベランダ。ベランダに観葉植物。「看護婦 さんの入るところは明るい雾囲気にしよう」。他の場所 から見えない暗いところも欲しいからとナースセンター に仕切をする。そこに重症の患者。しかしその外に重症 患者室を移す。元の暗い室には診察室としてロッカーを 置く。「重症患者室にはベランダを造らない」と言う。

重症患者室の横の部屋に風呂を置く。風呂に入って外が 見えるようにした。便所に手洗を置く。重症患者のよこ ろにテレビ。背の高い椅子は偉い先生の所に。ナースセ ンターに事務用机とソファーを置く。ナースセンターに 広い空の白い壁を置く。これはナースセンターのカウン ターの空であることが後で判明。ドクター人形を置く。
看護婦人形を置く。「大体こんなものです」。

質問至んな色が欲しいですか。「赤は欲しくない。 血を連想して危険だから。緑をもっと使いたい。緑の絨 求とかできれば良かった。絵を描くよりこちらの方が楽 しい」「どこからでも外が見える。5階から 6 階にして 景色を良くしたい。この辺にプールを造るのです。ちょつ と造って見ましょうか。この案の風呂は露天風吕の用に 外が見えるのです。この人形をプールで泳がしておきま しょう」と言って女の患者二人を横にして置く。自分人 形を指して，ロビーで何をするの。「タバコを吸う」そ のロビーの自身の横に女性の患者の人形を二人置く。重 症患者と言うのはどんな患者。「点滴などの治療をして いる」一人部屋は。「人部屋の方が良い。今は 6 人だ。 4 人でも大変なのに」二人部屋の仕切は。「カーテンは あった方がよい。着替えをするときなよ゙」今はどうなっ ているの。「カーテンもない。堂々と着替えをやっている」 「畳よりベッドが良い」この模型の迴りは全部外だね。「は い。できれば海が見えるのがよい」どうして海。「海を 見ると伸び伸びとした気持ちになる。山より海が良い。 もっと立体的に作りたい。エレベーター，一番上にサン ルーム。階毎に色々のものを入れて。体育館も」一人ぐ らいは寝ている患者もあっても良いのでは。「自分は寝 室の外にいたい」

議論自分の病室を特定しなかった。部屋を一つずつ 作って行く患者もあるが，今回は全体を作ってそれを分 割する作り方であった。なぜ四角な空間を作らないのか。 四角は複雑な空間を測定したり作ったりする時に便利。 アフリカの狩猟民族の住居は皆円形。それが農業集落に なると四角になる。しかし 2 回目の実験では意図的に開 放的にするために円くしたとも言う。

実験 2 回目 所用時間 1 時間 (10 時 20 分 $~ 11$ 時 20 分）約 1 力月後に行われた【「前と一緒のものを作るの ですか」いやだちらでも，好きなように $\mathbf{\Lambda}$ 前回之同一の 自分人形を「青いのを」と言って中央に。用意された壁 を長い間見回した後, 外壁を円く, その中に四角な部屋, 中央にデイルームを配置、プール，ナースカウンターを

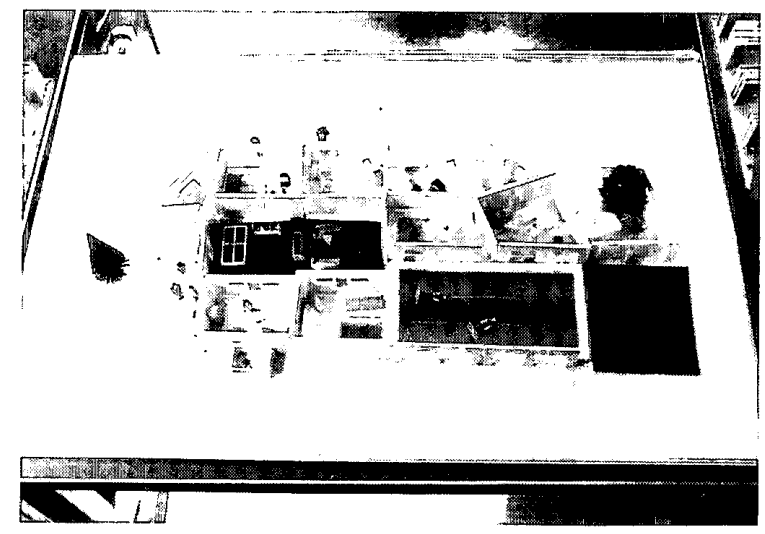

写真一3 被験者 ki 2 回目の作品 
置く。デイルームに芝生を切って緑の絨逮を敷き詰める。 その上にソファー, 自分を置く。ベッド, ベランダ, 盢, 風吕, 洗濯機を代用した冷蔵庫, 麻雀台, 樹木を置く。 玄関の三角屋根がしゃれて面白いよ言って配置。但し玄 関としてではなく。プールを壁で囲む。室内用とのこと。 階段を医師の近くの吹き抜け空間に。芝生でテニスコー トを。右端部分の室配置はあれこれと作り替えた。「こ んなものかな」と言ってまたあちこち追加。

質問「外壁が円いのは開放感を出すため。中の部屋 は今度は四角に作ろうと思った」ム「この部屋出入りでき ないね」と言って，そこをナースセンターから出入りで きる重症患者室に変更。健常者ほど作成時に同時に複数 の機能関連を処理できないが, 他の患者と違って予盾に 気がついて修正できる。この方法は寛解前の概念操作の 訓練に良いのではないかム「濃い色は淒い」ム前回の写真 を見せる。「今回の方が良くできた」。前回と較べて体の 調子は変わらないと言う。ムこれらの作品のモデルとな る病院はないと言う。「こんな病院なら退院したくない」 「写真を取らないのか」「また作りたい」

議論前回の案と円い外壁や室配置は良く似ているム 内部は前案より充実。患者の作品としては全体が壁で囲 われていない唯一の例。寛解期にあるためか非機械的, 非画一的で, 正面性の強調されない，色調の安定した作 品。

実験 2 被験者 Yo 母のみ健在 確執激しい一人っ子 大学 3 年時発症 平成 1 年他病院より紹介 精 神運動興奮が強く 2 回の入院治療後平成 3 年 3 回目の入 院中宗教団体の勧誘を契機に悪化 自殺の可能性 礼儀 正しく明るい

実験 所用時間 1 時間 07 分 (3 時 05 分 -4 時 12 分) 家具の説明途中で「もうわかりましたから作ります」と 玄関から開始。玄関両側の壁亡樹木ができるム手前から 奥に向かってできてゆく。各室が徐々にできあがる。室 の一部の壁を置くとすぐ家具を置く。中央の広い通路で 左右が二分され, 左右が徐々に進行山ナースカウンター と看護婦を置く。右にトイレを置く。中央にソファーを

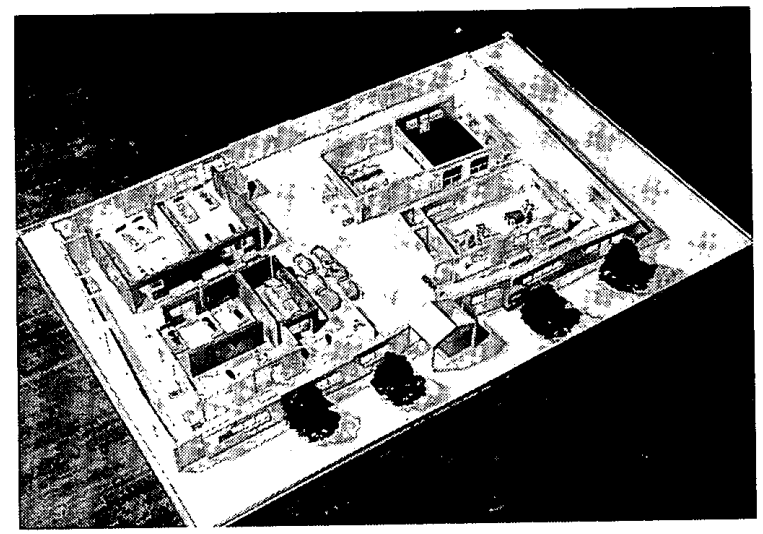

写真一4 被験者Yoの作品
作り自分を置くムトイレの横は診察室。ソファーの左に 会計のテーブル, カウンター案内人, 病室の一部, 中庭, 食堂兼売店の順に置く。病室が徐々にできあがる。ベッ ドとその上に横になった患者を置くム室群を囲うように 外周の廊下と外壁が，各室ができあがるにつれて少しず つ全体を囲っていく。

質問「テレビを見ながら会計の電光揭示の順番を 待っている」「カウンターで案内をしたい」「病室のブルー は好きな色」「大きな病院のイメージで作った」

議論、室内から外へのイメージがない。外部の樹木 もあるが，それは玄関を外からみたときのもの。中庭に 樹木がないム会計の前でポツンと一人で待っている姿は やや異常。本来ここは人の集まる場所、壁を置くとすぐ 家具を置く傾向。そして窓なし壁で囲んで空付きに変更 する傾向は，窓と囲うことを同時に考えられないためか \外周の廊下と壁は枠付けの可能性、左右対象で正面性 が強くやや機械的, 画一的であるが, 全体に予盾はなく, 他の患者と比較して, 作品にまとまりがあり, 概念統合 力は病歴が浅いためかまだ落ちていない。

実験 3 被験者Mo 両親健在 同胞 3 人第一子 高 卒後 9 年間勤務 昭和 46 年結婚一子 昭和 48 年発症 通院治療 3 回の入院 昭和 61 年以後 4 回目の入院中 家族関係希薄化幻聴や作為体験や被害妄想など活発 隔 離室希望 押入に隠れる

実験所用時間 1 時間 (2 時 45 分 3 時 45 分) $\Delta$ 立っ たまま。作業療法ではとても 1 時間はもたなかった 初できないと言って困っていた。玄関の中に自分やベッ ドを置く。便所, 医者, 看護婦, 販売機などを置いてゆ く。しかし置かれた物が患者に空間感覚を与えるのであ ろう，しばらくするとそれらを壁で囲うようになる。ム 途中で「良くできている」「病院らしくなった」「楽しそ うだ」とほめると以後順調に進むようになる。それも物 を置いて壁で囲う順序であるが。患者は誉められること があまりない。そのため大きな助けになった 途中で患 者の数をしきりと数えていた $\Delta$ 前回のYoと同じく作成 中に「巧くできない」「期待に添えない」と結果を心配

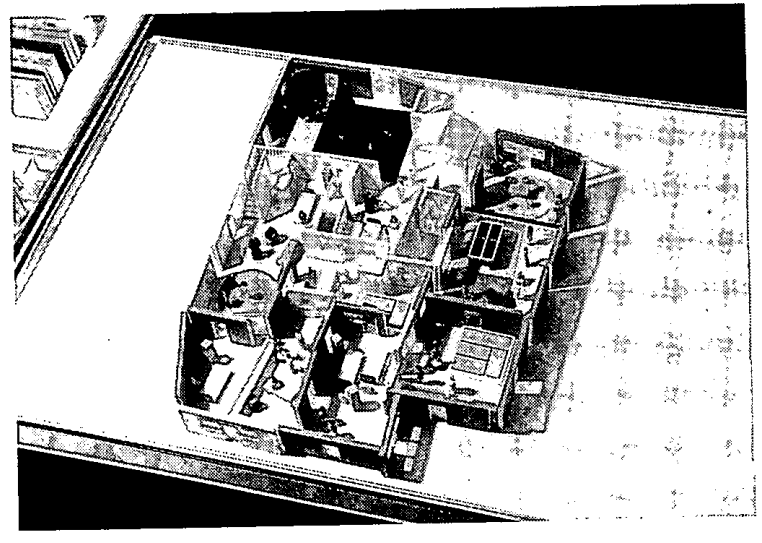

写真一5 被験者 Mo の作品 


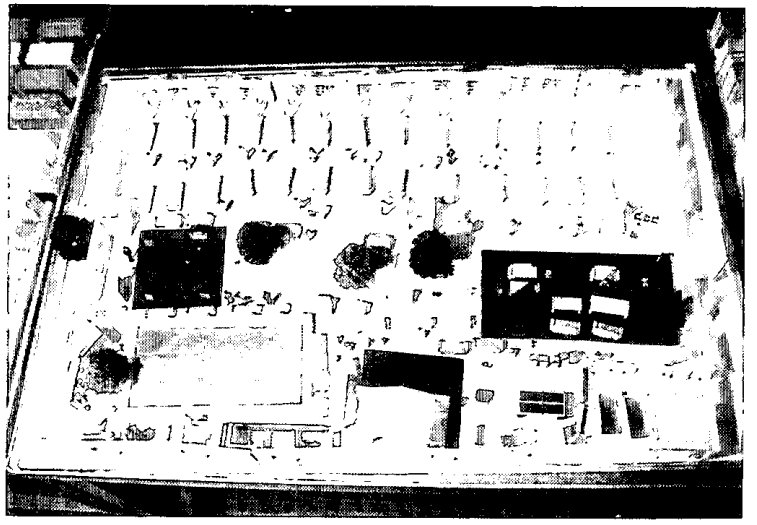

写真一 6 被験者 $\mathrm{Ok}$ の作品

する凹一度置いた物をすぐまた他の場所に移してしまう $\mathbb{\Delta} 3$ 畳の畳の上にテレビを置くとき 1 疊単位でテレビを あちこち置き換える凹女子病棟が長いためか女性患者を 多く置いた、終了間際, 南の庭の外を壁で囲う、制作中 は聞き取れない独り言を連発。

質問開始時に棚の中から自分人形を懸命に選んで置 いたが, 後で質問すると階段横のベッドの別の人形に なった凹被験者の面する葖を指して「こちらが南か」, そうだと答えたら作品の南側に芝生を置いた』「煉瓦色 の壁が好き」とこれを多用。他の被験者は病院らしくな いと言うことで誰も使わなかった。妄想型に固有な濃色 䕈しかったかと聞くと「楽しい」。「子供の頃した遊び, でも今は年をとった」と。

議論壁は組み立てられるまでは抽象的意味しかなく 取組みにくいため，具体的な家具や人形から置く、同じ 部屋にベッドとナースセンターがあったり，風吕とベッ ドがあったり予盾。部屋間の関係も不明確。連絡のため の廊下はない。廊下自身は特定の目的を持つわけではな い。連絡という，ある意味では機能的，概念的空間であ るので作りにくい。機能と機能の関係を整合的に空間化 する抽象的操作は困難 ه個々の空間が狭く，入組んでお り, 隔離室希望と関係がありそう、空間に予盾が多いが, 空間構成は変化に富み, どこか生き生きしたものが感じ られる。妄想型の特徵、中央前方より手前に向かって作 品ができてくる珍しい例。

实験 4 被験者 $\mathrm{Ok}$ 本年父と長兄死亡 在 17 才発症 高卒後他県就労転々 19 才精神分裂病 指摘も無治療 22 才大阪初回入院 帰郷後昭和 45 年当 院初診より 3 回の入院治療 昭和 49 年 4 回目の入院中 職業訓練校・外勤共失敗 院内で箱折り作業療法中 自 発性低下 無為 好褯的 心気妄想

実験 所用時間 46 分（3 時 29 分 4 時 10 分） $\Gamma 00$ さんなら巧くできるよ」「帰ってベッドで寝ていたい」「こ れで僕のことを何か調へているの」あまり積極的ではな い。できたら自分でできたと言ってと言うとまた作り出 す凹最初手前を除く三方をホワイトボードのアルミ枠に
沿いつつ空付きの壁で囲う。ベッドを横二列に並べる。 その手前に樹木をまた横に並べる。一番手前の領域に人 間, 卓球台, ソファー, 玄関, プール等を並べる。さら にベッド毎にロッカーと人形を配置。空白をもので埋め る様に配置、ベッドや人形を棚の右上から順に片手にま とめて㨡んで, それを順に置いて行く。空間を感じる様 子がない。その都度空間を吟味し，自分の作ったものを 見ながら次を作るという様子はない】最後に手前のアル ミフレームに沿って壁を並へ，玄関も何もかもその壁で 囲んだ。これはMoが完了直前に庭を囲ったのと同じ 枠付け行為であろうか。

質問何点ぐらいの出来 $\lceil 60$ 点ぐらいかな」。また作っ てくれる「もう作りなくない」昔のこの病院は木造の 大部屋であった。それが良かったと言う。今の病院は嫌 いと言う。そのためベッドがたくさん並んだのだろうか。 ベッドの中で自分のベッドはどれかと聞くと，一番端の 隅の物という、自分人形は玄関のところで病院内を向い て立っていた。自分はどこかと聞かれてンファーのとこ ろに移動。

議論 Moの妄想型で豊かな自閉に較べて, 破瓜型の

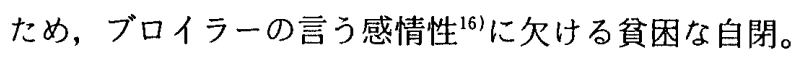
無為症状が良く現れた作品、市橋は慢性分裂病患者の特 徵として, 対称, 羅列, 積み重杖, 構成不能を挙げてい る。特にここでは羅列が顕著に現れている ${ }^{14)} 。$

また河合は箱庭の直感的印象の大切さを強調し，その 中でも統合性を挙げている。非統合的なものの特徵とし て, 分離, 粗雑, 貧困, 力の釣り合いを感じさせない固 定的なもの, さらにこの作品に特徵的な機械的配置や画 一性を挙げている"1)。幾何学的模様や装飾的図柄で隅々 まで埋め尽くすミンコウフスキーの病的幾何学主義と同

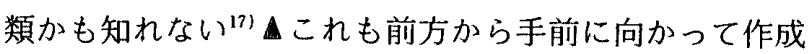
して行く例。

実験 5 被験者 $\mathrm{Mi}$ 父健在 幼少時母死亡 同胞 2 人第二子 高卒就労後 19 才発症 3 回の入院後昭和 49 年当院へ通院 昭和 61 年 2 回目の入院治療中 就労失 敗 院内作業従事 意欲低下 多彩妄想 連合驰緩 人

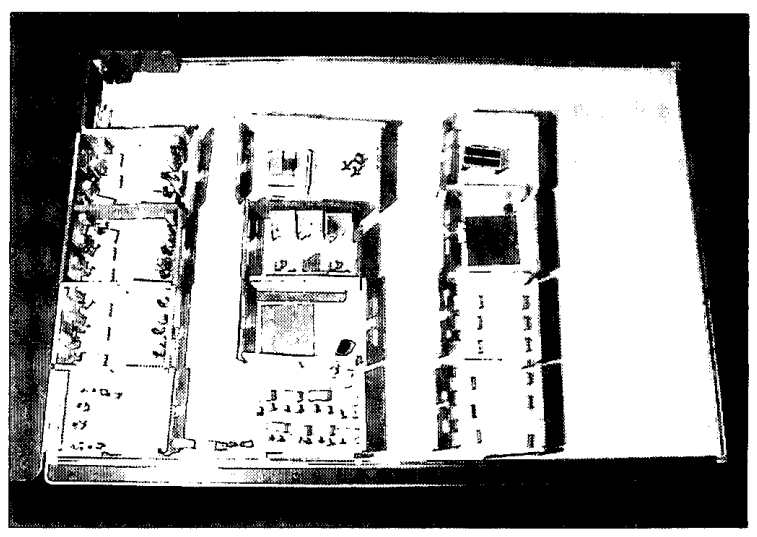

写真一7 被験者 $\mathrm{Mi}$ の作品 
格平板化

実験 所用時間 40 分（2 時 24 分 -3 時 05 分) $\boldsymbol{\Delta}$ 何回

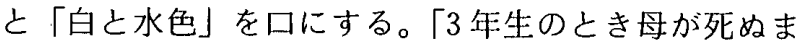
で白と水色」と言う。壁の色を見ると，それが引き金と なって，辛さの表現として，その時々でこのような言葉 が出る。病状表現である。白と水色と言いながら実際に 使う壁の色は白，ピンク，その他色々であるム壁で囲っ て部屋を作り, 家具や人形を置いて行く。最初, 左手前 アルミ枠に密接して, 病室を 3 室連続して作る。健常者 には左手前からの制作ばかりであった。娛楽室が欲しい と言う。食堂もと言う。各病室にベッドを6個ずつ。各 ベッドに人間を立てて置く。男性室 2 室と女性室 1 室に 分けた。ロッカーを各人に置く。不足したと言うのでま た出す。「私の心理状態をテストするのだ」と言う。便 所を置く。食堂配置。その奥の部屋にカラオケ。電話を 食堂に。「にいちゃんと合わないので死にたいという」。 病室列に対して食堂, 娛楽室列, その右に「こっちに病 室列を作りたいが人形がないので作れない」。空き部屋 でも良いからと言うとベッドのみ置いて作る。「もう止 めても良いか」と聞くのに対して，もうできましたかと 言うとまた何か作り始める。

質問 自分がナースセンターに一番近いところのベッ ドにいるのは「看護婦さんと友達になりたいから」。良 くできたと誉めると泣き始める。また作ってくれるかと 聞くと，「作る」と言う。樹木は山の暗いイメージを連 想するからいやと言う。外は余り意識していない。ホワ イトボードの向こうは外来棟と言う。南の方向はどちら か考えていないと言う。木目の壁は古くさいので凄いと 言う。作業を終わって州るとき，食堂で林檎の皮を剝い ているところに出会った。チョコレートありがとうと笑 顔で手を振った。

議論部屋間の関連は希薄。作成中の話を聞いている とつじつまの合わないことが出てくる。思考を奪われる と言う恐れの体験がある。調べられていると言う気持ち が強い。作品は $\mathrm{Ok}$ 同樣画一的, 機械的。食堂, 病室, 娛楽室と作るが，それは病院とはそのような物があると ころだから，それを作ったと言うまで。自分の作品と対 話して，自分の中で制作の面白さが広がり，夢中になる と言うのではない。作成を楽しんでいない。YoやMo のような豊かさがない。人間性の崩壊であろうか。ブロ イラ一は感情的鈍麻を分裂病の特質の一つに挙げる。感 じるところが人格の中から欠落しているためであろう か。人間の本性が「空っぽ」の感じの「人格の形骸化」。 実験 6 被験者 Is 父健在 本人出産時母死亡 同胞 2 人第一子 大学 2 年 19 才で初発 昭和 45 年他県で入 院 昭和 53 年当院入院 昭和 63 年急性増悪で 3 回目の 入院中幻聴 連合弛緩 時折就労不能も包装会社勤務 実験所用時間 17 分 (2 時 32 分 2 時 49 分) $\Delta$ 実験
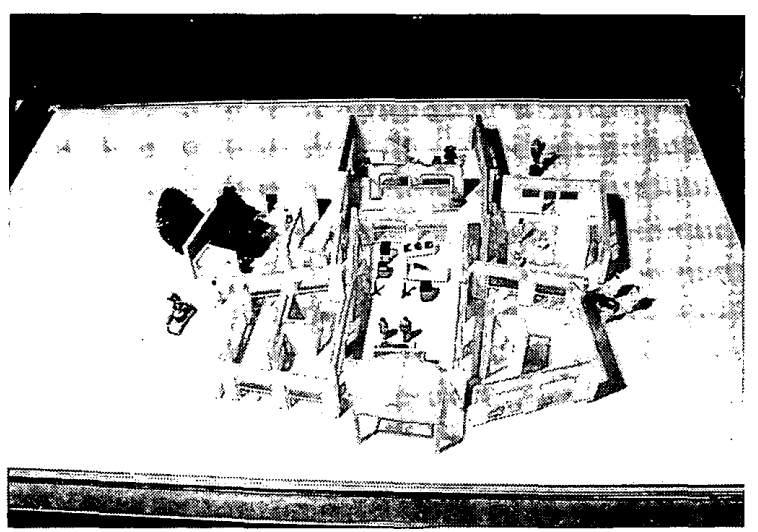

写真一8 被験者 Is の作品

方法を正しく理解さすのに苦労山自分人形はネクタイを した人形 $\Delta$ 中央に正方形の部屋を作り，ベッド，力ラオ ケ, 自分, テレビ等を置く: ベッドの上の人形を寝さし て，死んでいる人と言い「これで終わり」。もう少し作 れないかと言うと続けるム手前の壁を 90 度開いて, 手 前に長い部屋を作り始める。後で一番手前に玄関に置い て塞ぐ。玄関と部屋の間にスクリーンを立てる。その両 側に便所。さらにそれらの向こうに，左右に対称的に円 い絨逑を敷き,その上にそれぞれ椅子を一つずつ置いた。 それらを壁で囲って，右に女性，麻雀卓を囲む看護婦と 医師のいるくつろげる部屋, 左にカフェテラスを作る。 カフェテラスの中には大きな樹木や階段がある。さらに 中央の最初に作った部屋の向こうに一部屋作る。これは 入院していたおばあちゃんの死んだ部屋という。中央の 自分人形は手前に置いたベッドの横に移動し, その横に は自分の嫁さん，ベッドの上に寝かせてあるのは先に， 死んだ人と言った人形を前のベッドから移したもので, これが父親と言う。前のベッドには犬を置く。「お嫁さ んと二人で見舞いに来ているのだ」と言うが本人は独身。 質問便所には時々逃げ込む。カフェテラスにある大 きな木はクリスマスツリー。ここでパーティーをする。 おばあちゃんが死んだ部屋ではお経をあげる。この部屋 の青とシルバーの壁は弟の好きな色。自分は黄色ぽい壁 が好き。海岸の出身だから温かい色がよい。退出後我々 が作品を撮影中に缶ジュースを差し入れに来てまた少し 話し込んだ。

議論 全体が対称形 $\Delta$ 優格概念として家族のことが 度々出てくる。個々の部屋に家族についての意味付けが してあるム部屋を一つずつ置いて行くだけで, 部屋間の 連絡はないム一つの壁はそれがまず，ある部屋を囲うと いう意味を持つ。しかし同時に隣に廊下や部屋ができれ ば,その壁は同時に他の部屋を構成するという意味を持 つ。しかしこのような壁の二つの意味を考えながら, 空 間を構成することができない。ブロイラーは分裂病の四 つの症状の一つに両価性 ${ }^{16)}$ を挙げ「分裂病者は連合能力 の衰弱のため，事の様々な側面を一つにまとめて考える 


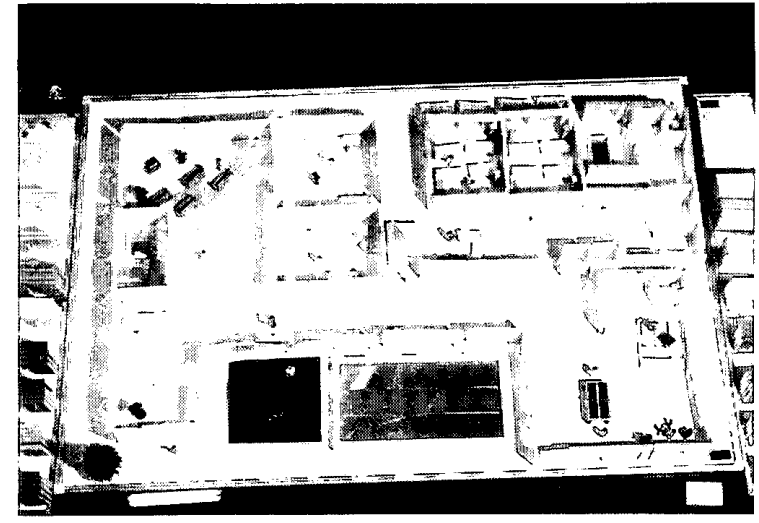

写真一 9 被験者 Se の作品

ことが出来ない」としている中央の部屋を除いて, 全 ての部屋に便所ユニットがある、全体として窓が大変多 い。

実験 7 被験者 $\mathrm{Se}$ 女性 22 歳健常者 教育学部学生 養護課程

実験 所用時間 1 時間 08 分 (2 時 26 分 -3 時 34 分) 左手前の入り口から, 受付, 待合い, 診祭, 廊下, 娛楽 室, 2 階と想定している洗濯室, 風呂, 病室, その前の 娱楽室と, 全体がまとまらないので, 人が入って来る入 りロから順番に作っていったと言う。良く考えながらま た壁も少しずつ修正しながら作った、自分人形は娛楽室 の卓球台の前においたが，その他の人形は完成の宣言を した後に眍置した。㝵入院経験はあるがそれとは関係な いとのこと业プール, 樹木, ベランダ, 芝生など外部と の空間的つながりもある凹部屋を作ってから家具類を配 置。

実験 8 被験者 $\mathrm{Ya}$ 男性 23 歳 健常者 工学部学生 実験 所要時間 1 時間 02 分（4時 10 分 5 時 12 分） 他の健常者と同様に分裂病患者に較べて最初長い時間を かけて構想を練る、左手前の青い病室から作って行く。 それが左の中庭や事務所に，あるいは右方向の入り口の 方に延びて，最後に右の診察室ができる』自分は入院し ている彼女のため，階段のところでジュースを買ってい るム基本的に壁ができてから家具や人間を置く。

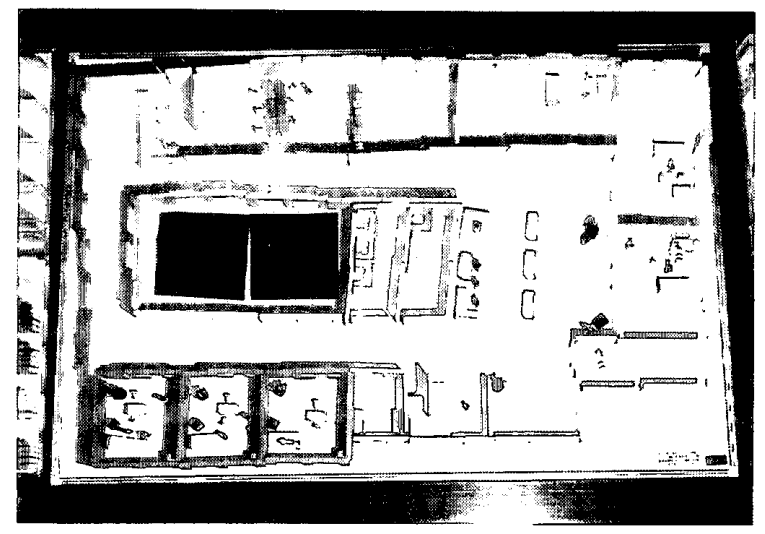

写真一10 被験者 Ya の作品

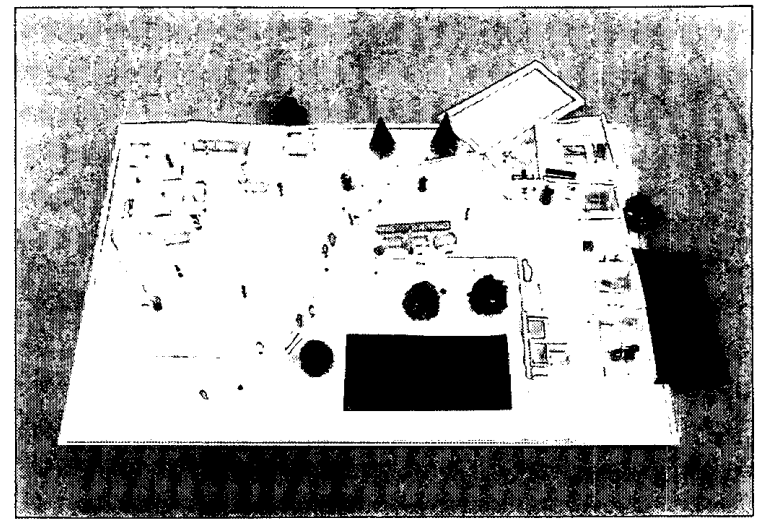

写真一11 被験者 Fu の作品

実験 9 被験者 $\mathrm{Fu}$ 健常者女性 20 歳 工学部学生 実験 所用時間 1 時間 21 分 (10 時 39 分 12 時 00 分) 外周壁を左手前入り口部分から順に試行錯誤を重ねなが ら作り，その内側に部屋を作って行く。斜めの壁は室を 広く見せるために，意識的に作ったム子供の頃小児科に 長くかかっていたので，自分人形は病室には入れずに小 児科の診察室の前に置く。針葉樹より落葉樹が好き。

\section{5. 考 察}

\section{(1) 概念操作}

分裂病患者は一般的に抽象的な概念操作，すなわち複 数の機能を思い浮かべ，互いの関係を統合する観念連合 とそれらの空間的具現が不得意になる。

これに関連して横田 ${ }^{18)}$ は認知図の描画における健常者 の全体分割型に対して, 患者は区画連合型で表象が断片 化し，断片化の進行につれ具体化と抽象化に分極すると した。さらにこの現象は対象に対する視点の適切な距離 の障害によるとした。これらは以下の具体物の配置や破 瓜型の画一化や正面性の問題に関連する。⿴囗廊下等の 非目的的，手段的空間がなくなる。20形とか家具穎 等の具体物を先に置いて,それらを囲う形で抽象的な工 ニット壁を置く。これは具体物の方が抽象物に比べてそ の意味が明確であることによる。H．オズモンドは便所 や洗面所を分かりやすい所に配置し, 部屋やロッカーの 屝に記名するようによ言う'19)。このことは個々の場所が ユークリッド幾何学にもとづく均質的空間ではなく, 固 有の相貌を備え，明確なただ一つの意味を表示すること の必要性を要求する。目一つの部屋の中に風呂と冨が 同居したり，廊下がなかったり，カウンターにベッドが 併設したりする予盾が空間構成に現れる。

（2）両価性と記号性

患者達は一つの壁を一つの部屋を囲うために立てる。 しかしそれが同時に別の壁を構成する物であることをそ の場では理解しない。空間や物の両価性 ${ }^{16)}$ を理解できな い。同一空間や物がそれぞれの意味每に別物として立ち 現れる傾向にある分裂病患者にとっては，個々の空間は 
その空間とその意味とが一対一に対応する記号的空間で なければならない。この記号的空間の特性のため,この 空間は健常者にとっても交通や避難に有効である。加藤 は高松病院の設計にこれを実践しだ5)。同様の理由で精 神病院には, アイデンティティーのある認知しやすい空 間が求められている199。

(3) 作成順序

健常者は最初しばらく手をつけずに構想を練る。壁か ら置いて行く。左手前から周辺枠に沿って壁が延びて行 く。外部と内部空間の関係が密である。一方分裂病患者 は一つの場所から順次周辺に作成領域が広がって行く。 前方から手前に広がってくるものが 3 例と一番多く，そ の他は手前加前方, 左手前加周辺, 中央加周辺之 なっている。道具類を置いてそれを壁で囲って行く。最 後に全体や庭を壁で囲う枠付けも数例見られた。河合 ${ }^{11}$ は箱庭の各領域に対し, 手前之前方を肉体と精神, 左と 右を内的・無意識, 外的・意識とする。

(4) 庇護的空間

患者は隔離された空間を好むと言われているが201，現 在隔離室に入ることを自ら希望しているMoは，小さ な二人部屋や個室を作り，その他の患者は他の人と同居 する多人数部屋を好んだ。

市橋 ${ }^{201}$ は閉鎖空間を枠付け問題として解説している。 両者は原理的には同じであると説かれているが，ここで は枠付け問題は後述の問題に限定し，閉鎖空間を庇護的 空間の問題と呼ぶことにする。市橋によると分裂病患者 は閉じた空間になじみやすい。彼らは自己身体を守れず， それを維持するために雨戸を閉じ，窓に目張りをし，家 に引きこもり，物理的心理的に自閉の構えを強くする。 治療は庇護的空間を用意し, 患者の空間を保証し, ノレ ン分け的に病者が自らの空間を獲得して行く過程である と言う。また H. オズモンドは安心感のある包み込むよ うな空間が求められていると言う191。石川4 の人というのは自分の殼に閉じ込もって他人と交われな い.......自分の領域と決まったところへじっと身を縮じめ て、身じろぎもせずに自分を守っているより仕方がない。 …ああやって自分の周りに目に見えない壁を作っている のだな」と言う。

隔離室希望の Moが，小さな空間の複合体のような 作品を作ったのはまさしく庇護的空間の例である。しか しこの実験ではMoを含む罹病期間の長い女性患者以 外は開口部面積率が大きく, 開口部のない壁が健常者よ り少ない。閉鎖的空間を必要とするのは特定の病状の患 者なのかもしれない。

\section{(5) 人間の扱い}

若い患者は自分人形を公共空間に置いた。心は社会に 向いているのだろうか。慢性分裂病患者の女性二人は ベッドに自分人形を配置した。男性の一人は好䙏的であ
るがベッドの横のソファーに配置, 他の外勤に出ている 一人は父を見舞いに行って父のベッドの横に立ってい る。自分人形以外の人間の配置に付いては明確な傾向は 見られなかった。市橋 ${ }^{14}$ によると，寛解過程では人物の 描画がもっとも遅れるという。

\section{(6) 色 彩}

色数については個人差はあるが患者と健常者との差は ない。患者の方が濃い色を多数使用し, 健常者は淡い色 を殆ど全色使用。薄いピンクは被験者全員に使用された。 妄想型は濃い色, 破瓜型は淡い色を好んだ。多く置いた 色が必ずしも被験者が好きな色ではなく, 大切な空間と か象徵的な空間に好きな色が使われた。

\section{（7）枠付けと壁の問題}

分裂病者はしばしば枠を周囲に巡らせてその中に箱庭 を置くという河合の指摘に示唆を受けた中井は，保護的 な意味から絵画療法や箱庭における枠付け法を完成させ た。武野211は患者が堆肥の絵を枠で囲んで「しっかり積 んである感じを出すため」と言い，安心感を得ると説明 している。当実験では河合や武野に類似する被験者の以 下の枠付け行動が観察された。回 Ok は最初長い壁をア ルミフレームに沿って作り, 最後に今度は手前のアルミ フレームに沿って, 同様の壁を作りその中に玄関も何も 囲んでしまった。2 $\mathrm{Ki}, \mathrm{Ok}$ のベランダを除いて患者達 の作品で壁の外に何かがあるものはない。しかし健常者 や子供の作品には壁の外に芝生や樹木等があることが多 い。3 Yoの作品には全体を取り巻く廊下と壁の染があ る。

\section{（8）閉鎖的空間と壁}

1）使用壁面積 壁面積は空及び扉面積を含んだも の。(1)患者は健常者に較べて壁面積の使用が少ない。こ れは患者の作品は一般的に小規模で, 廊下などもないこ とが原因である。また患者は壁によって空間を作るとい うより，家具，人などを置くことの意識が健常者に較べ て強いことも関係している。ただし(2)䍜病期間の短い患 者は使用面積が大きい。また(3)壁の使用枚数についても 面積と同梯である。図一2, 3 参照。

2）開口部と閉鎖性井上221は家屋の外観の描画によ る家屋画二面法によって，窓なしや戸なし等の開口部や ベランダ, 坦根が分裂病の自閉性, 自我境界の防壁性,

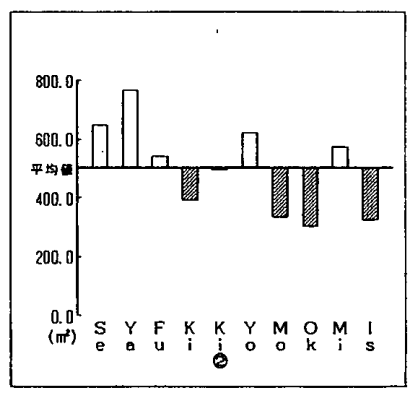

図一2 壁の総面積 (平均偏差) 


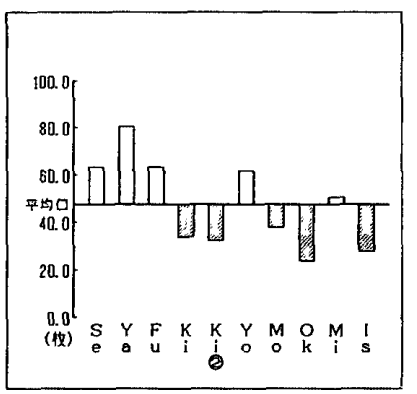

図一3壁の使用枚数 (平均偏差)

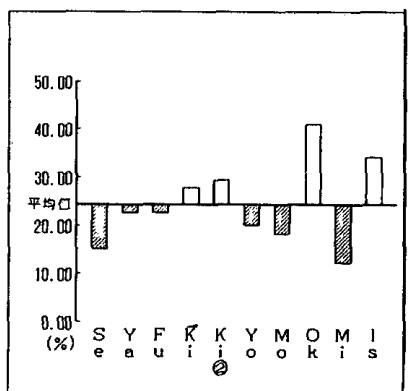

图一-4 壁面積に占める開口 部の割合 (開口面積) 総面積 $) \times 100$

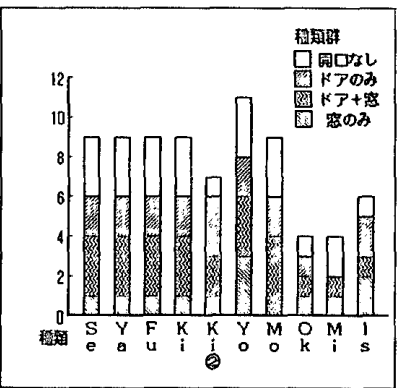

图一7開口部の種類による壁の分類（使用種類数別分頪）

浸透性，流動性の反映と解瀵されるとした。しかし悹， 屝に関しては当実験では以下のように同様の結果が得ら れなかった。またベランダは内外空間の結節点であり内 から外へ開かれた交流を反映した場所で大学生群に特徵 的としているが，分裂病者にも使われた。

2-1）開口部のない壁の使用枚数開口部とは空と扉 を意味する。開口部のない壁の枚数が全体枚数に占める 割合を見ると健常者に較べて患者の割合が小さい。

2-2）開口部面積率 全体の壁面積に対する開口部面 積の割合は，健常者と患者との差はないが，女性患者の 罹病期間が長くなるほど開口率が低下する。しかも悹に よる開口率が特に低くなる。図一4参照。

2-3）扉使用率全体枚数に対する，扉のある壁の使 用枚数の比率は健常者に較べ患者の使用率が高い。特に Mi やMo は開口部面積率は最小で, 屝使用率は最大で ある。すなわち㥶が少ない。図一 4,5 参照。

3）壁の長さ別使用頻度 $5.4 \mathrm{~m}$ の壁を一番多く使用 している。慢性分裂病患者は，短い壁を使っていない。 しかし隔離病室を希望していたMoは短い壁を多用し て小室を作っている。また慢性分裂病患者は, 他の被験 者が多種類の壁を使用するのに対して，2 種類の壁しか 使用していない。図一6参照。

4）壁の種類の使用枚数開口部の型によって壁の種 類分けを行うと, 健常者も分裂病者もほぼ一通りの型の 壁を使用するが, 慢性分裂病者は種類数が少ない。図一 7 参照。

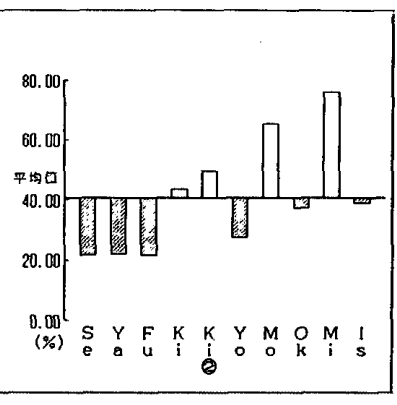

图一5 全体の壁のうち丽がある 壁が占める割合 (平均偏 差)

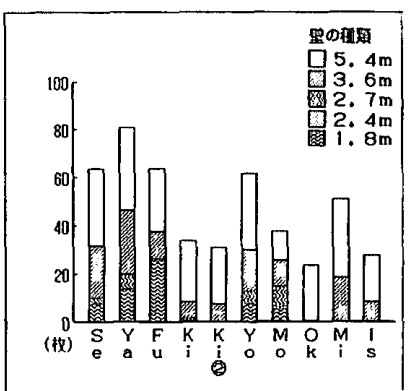

図一6 壁の長さによる分類 （使用枚数）
（9）健常者と分裂病患者の作品の全体的印象の比較 河合は箱庭を見たときの全体的感じ，印象の大切さを 強調している"1。分裂病者の作品の質的性格の多様さに 比べて, 健常者の作品は皆一様に一つの人格かと思える ほど似かよっていた。分裂病は奥が深く、それは単なる 症候群の一つであると言われるのが良く解る。

（10）破瓜型，妄想型から見た作品の分析

中井久夫到に上ると破瓜型の特性は, 周期的, 常同的, 対称的, 静的, 貧寒, 非個性的, 典型的, 薄い色, 少色, 描線の任意性と自発性を殆ど意識的に回避するなどと なっている。これに対して妄想型の特性は, 非周期的, 非常同的, 非対称的, 動的, 豊富, 分化, 個性的, 個物 的, 濃い色, 多色, 描線全体にゲシュタルト的なまとま りがあるなどとなっている。これを被験者の破瓜, 妄想 の別から比較してみるとその特性が現れている。まず破 瓜型は, Ok, Ki であるが, 特に Ok の作品は周期性, 非個性的，薄い色，非自発性などにおいて良く現れてい る。Kiについては顕著でない。破瓜型であるがやや妄 想型の $\mathrm{Mi}$ とIsにおいては Mi の方がその特徴が顥著 である。両型の中間であるYoはやや破瓜型に近い印象 である。破瓜型に近い妄想型のMoは, 非周期性, 動的, 豊富, 個性的, 濃い色, 多色などその特徴が顕著である。 （11）正面性と視点の乗り越え

$\mathrm{Ok}, \mathrm{Mi}$, Is の各作品には正面からの視線は感じられ るが，左または右からの作者達の視線は感じられない。 Yoには若干の左右の視線が感じられる。Kiには十分な 左右の視線が感じられる。Moにも正面, 左右の視線が 感じられるが，全体的に希薄である。これらに対して健 常者達の作品は左右非対称で, 廊下が左右に走り, 正面 と左右の十分な視線がある。患者達に左右の視線がない のは，正面に座して作者達が自身の視点を制作ボードの 左なり右なりに移動してその位置から眺めるという, 宮

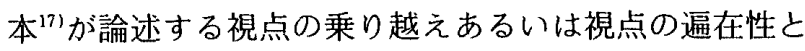
言われるものがない。宮本によると精神の運動により， 視点の移動は対象に立体感を与え，それによって外界を 遠近法的に捉え, 感性的把握の場としての風景発見の重 要な根拠となる。ここで言う風景とはシュトラウスの引 
用で地誌的空間に対するもので，ビンスワンガーの定位 的に対する気分的空間と同じものである。視点の乗り越 えのできない患者達にとって残されたものは, 正面性, 奥行きのない平坦さの地誌的空間のみとなる。一方健常 者達は風景的空間に生き, 日常生活で地誌的空間が露出 することはまれにしかない。

\section{結 語}

1）治療的効果

患者達が興味を示し刺激を受けた。作成対象が日常的 建築空間（病院）で対象や道具に制限があるため患者の 奥深いものを露にすることもなく発症促進効果がない。 また重症患者もその描画能力に関係なく作成可能であ る。このため治療的効果が予測でき, 今後同一患者に繰 り返し適用してその変化を調査する。

\section{2) 観念的操作の異常}

観念連合弛緩や観念の断片化による部分増殖的作成順 序, 廊下の欠落, 空間の機能的-論理的予盾, 抽象的道 具より具体的道具の先行, 視点の乗り越え不能による正 面性の強調, 壁面積・使用枚数の減少, 壁使用種類の減 少等の特徴が作品に見られた。

3）両価性と記号性

壁に二つ以上の意味を持たせながら空間を構成できな いので, 患者達には物と意味が一対一に対忘した空間が 望ましい。

4）庇護的空間亡枠付け

隔離室希望者は窓の少なく, 出入口の多い小室群から なる庇護的空間の作品を作成した。作品全体を壁や廊下 で取り囲む枠付け行為があった。

5）作品の全体的印象や破瓜と妄想型患者間の表現的相 違

患者の作品が質的に多樣であるのに反し, 健常者の作 品の全体的印象は同一人物かと思うほぼ類似している。 破瓜型の貧寒や画一, 繰り返し, 淡色的傾向, 妄想型の 豊富や個性, 非常同, 濃色的傾向が作品に良く表現され た。

\section{その他}

前方から手前に置いてゆく独特の配置順序が数例見ら れたがその意味は不明。また自分人形の配置場所やその 周りの情報についても今後の課題である。

以上により当方法の, 治療的効果への期待と, 患者の 特異な世界を心像として表現するための有效性を明らか にした。そして心像は基本的空間性を目に見えない形で 支えている基準であるから，この方法による今後の心像 の研究の積み重ねが, 患者の必要とする建築空間を解明 し，それが設計者の空間構成の指針となるものである。

\section{参考文献}

1）野村東太ほか：精神病院入院・退院患者の特性からみた 社会復帰のための環境条件に関する考察, 日本建築学会 計画系論文報告集，第 410 号，pp. 77 85，1990. 4

2）野村東太任：精神病院入院患者の特性よりみた看謨単 位の再構成に関する考察 日本建築学会計画系論文報告 集, 第 359 号, pp. $31 \sim 38,1986.4$ その他精神医療施設 の計画に関する一連の研究

3）加藤邦男：リハビリテーション医学全書 22 「精神障害」 第 2 版，医霜薬出版株式会社，昭和 48 年 8 月

4）加藤邦男, 石川信義：治療環境ししての精神病院建築, 病院，第 40 巻、第 10 号, 医学書院, 1981.10

5）加藤邦男 : 精神病院に関する一建築家の覚え書 精神医 療 13 巻, 第 $1,3,4$ 号

6）坂戸省三：創作・表現行為および空間的表現の様態とそ の意味の箱庭療法を通じての考察, 日本建築学会計画系 論文報告集，第 307 号, pp. 80 90, 昭和 61 年 9 月

7）坂戸省三：男女それぞれにおける空間性の発展過程，日 本建築学会計画系論文報告集, 第 377 号, pp. 97 104, 昭和 62 年 7 月

8）坂戸省三：男女の空間的諸特性と世界像の形成，日本建 築学会計画系論文報告集, 第 402 号, 1989.8

9）坂戸省三：人間における世界像形成の生物学的基礎につ いて，第 421 号, pp. 111 120, 1991. 3

10）山中康裕ほか：箱庭療法 その技法之適応，芸術療法講 座 3，山中康裕ほか編，星和書店，1981

11）河合隼雄：箱庭療法入門, 誠信書房, 昭和 44 年

12）河合隼雄: ユング心理学入門, 培風館, 昭和 56 年

13）山中康裕：児童精神療法としての心像分析について，芸 術療法講座 3, 山中康裕ほか編, 星和書店, 1979

14）市橋秀夫：時空間障害と描画, 臨床描画研究 Annex 3 , 一描画を読むための理諭背景一, p. 132, 金剈出版, 1991

15）青木健次：バウムテスト, 臨床描画研究 $I$, 特集描画テ ストの読み方, 家族画研究会編, 金剛出版, p. 68, 1986

16）ブロイラー：早発性痴呆または精神分裂病群 訳：保崎 秀夫ほか, 医学書院, 1978

17）宮本忠雄：空間と空間的思想, 現代思想 1-1，1973

18）横田正夫ほか：長期入院の精神病患者における䜑知地図 の断片化，精神医学 第 28 巻, 10 号, 1986.10

19） H. オズモンド：精神科病棟設計の基礎としての機能 環 境心理学 5 , 環境計画, 誠信書房, 1957

20）市橋秀夫：他技法との比較，中井久夫著作集, 別巻 風 景構成法, 山中康裕編集, 岩崎学術出版社, 1984

21）武野俊弥：染強調砂箱による分裂病者の箱庭療法過程一 伜強調砂箱の意義一, 箱庭療法研究 2 , 河合隼雄・山中 康裕編, 誠信書房 1985

22）井上亮：風景構成法と家屋画二面法, 中井久夫著作集 別巻風㽡構成法, 山中康裕編集, 岩崎学術出版社, 1984

23）中井久夫：精神分裂病状態からの寛解過程，分裂病の精 神病理 2, 東京大学出版会, 1977

24）衛藤進吉：急性分裂病の回復過程における世界図式の変 要, 芸術療法 Vol. 16, 1985

(1991 年 12 月 9 日原稿受理, 1992 年 3 月 23 日採用决定) 